\title{
Vitamin C, A and E supplementation decreases the expression of HSPA1A and HSPB1 genes in the leukocytes of young polish figure skaters during a 10-day training camp
}

\author{
Małgorzata Żychowska ${ }^{1 *}$, Zbigniew Jastrzębski ${ }^{1}$, Grzegorz Chruściński², Monika Michałowska-Sawczyn² and \\ Alicja Nowak-Zaleska²
}

\begin{abstract}
Background: Overexpression of HSPATA and HSPB1 has been shown to indicate stress and the degradation of damaged proteins. Therefore, the expression of these genes is often evaluated during exercise. Vitamin supplementation in young athletes may affect the expression of these genes, and help to maintain health and improve the effects of training.

Methods: Fourteen top junior female athletes (age 14-15y \pm 0.3 SD, body mass $51 \mathrm{~kg} \pm 5$ SD, and BMl of $20.15 \pm 0.9$ $\mathrm{SD}$, time in professional training $8.5 \mathrm{y} \pm 0.5 \mathrm{SD}$ ) attended a conditioning camp that included meals planned by a team dietitian. To examine the effects of vitamin supplementation on antioxidant status we supplemented the athletes with either vitamin A (16 ug/ $/ \mathrm{kg} /$ day), vitamin C (8 mg/kg/day) and vitamin $E(1 \mathrm{mg} / \mathrm{kg} /$ day) or an inert placebo. Blood samples were taken before and after (12 h post) the camp to assess the relative expression of HSPA1A and HSPB1 mRNA in leukocytes via quantitative reverse transcription polymerase chain reaction (qRT-PCR).

Results: Overall, participants trained $\sim 135$ min daily (1345 min total). No statistically significant differences in HSPA1A and HSPB1 expression were observed between the groups before the camp. In the unsupplemented group, there was a non-statistically significant increase in HSPA1A expression (100\% change) and a significant increase (37\% change, $\mathrm{p}<0.05)$ in HSPB1 expression over the study period. The supplemented group experienced a significant decrease in HSPA1A (40\% change, $p=0.01)$ and HSPB1 $(25 \%$ change $p=0.03)$ expression over the study period.

Conclusion: Our results indicate that supplementation with antioxidant vitamins decreases HSPA1A and HSPB1 mRNA expression in leukocytes, and thereby may reduce exercise-induced stress in young athletes, not only during training, but also in sports competitions.
\end{abstract}

\section{Background}

Heat shock proteins are well-known effectors of the cellular stress response. Transcription of the genes encoding for heat shock proteins can be induced by numerous factors, including thermal, oxidative and environmental stress, as well as exercise and pathophysiological processes [1-5]. High and moderate intensity endurance exercise alters gene expression in human white blood cells

\footnotetext{
* Correspondence: zychowska.m@gmail.com

'Department of Health Promotion, Gdańsk University of Physical Education and Sport, Ul. Górskiego 1, 80-360 Gdańsk, Poland

Full list of author information is available at the end of the article
}

[6]. Changes in gene expression in the muscle are also reflected in peripheral blood leukocytes, and indicate a systemic response to exercise. Increased expression of HSPA1A and HSPB1 prevents apoptosis and DNA damage [7], and overexpression of these genes enhances tolerance to thermal stress. Increased HSPB1 expression is also associated with the degradation of damaged proteins $[8,9]$. Physical effort performed at elevated temperatures and the large amount of heat generated endogenously by the organism during exercise are both important factors that can stimulate the expression of these genes [10].

\section{Ciomed Central}

(C) 2015 Zychowska et al.; licensee BioMed Central. This is an Open Access article distributed under the terms of the Creative Commons Attribution License (http://creativecommons.org/licenses/by/4.0), which permits unrestricted use, distribution, and reproduction in any medium, provided the original work is properly credited. The Creative Commons Public Domain Dedication waiver (http://creativecommons.org/publicdomain/zero/1.0/) applies to the data made available in this article, unless otherwise stated. 
The anaerobic character of the physical exercise performed by figure skaters causes muscle damage and increased production of reactive oxygen species (ROS), leading to oxidative stress [11,12]. Supplementation with antioxidants may prevent oxidative stress $[13,14]$ and muscle damage [15] during intensive training. The antioxidant vitamins $\mathrm{C}$ and $\mathrm{E}$ are commonly used as sports supplements [16]. Leukocytes, and in particular granulocytes, have an enormous capacity to produce ROS [17]. It has been suggested that leukocytes and erythrocytes in peripheral blood respond differently to supplementation, with leukocytes having a greater sensitivity than erythrocytes [18], and a reduction in oxidative stress occurs in response to supplementation with vitamins $C$ and $E$ [18]. Increased total antioxidant status (TAS) and higher levels of plasma iron have been shown in athletes treated with vitamin $C$ and $E$ after endurance training [19]. In addition to oxidative stress and environmental stress, temperature can also induce the expression of genes encoding for heat shock proteins. The greatest exerciseinduced increase in expression of heat shock proteins was seen in HSP70 and HSP27, which are considered to be sensitive to exercise training [20].

In this study, we investigated whether supplementation with the antioxidant vitamins $\mathrm{C}, \mathrm{A}$, and $\mathrm{E}$ changes the expression of HSPA1A and HSPB1 mRNA in young female skaters undergoing long-term physical exertion. We hypothesized that increasing their antioxidant capacity would attenuate the effects of exercise-induced stressors and thereby inhibit the expression of HSPA1A and HSPB1 in the supplemented group. We assumed that uniform environmental conditions, similar diets, and comparable training intensities would allow us to properly assess the impact of antioxidant supplementation on expression of the HSP genes.

\section{Methods}

\section{Characteristics of the study group}

The study participants were 14 skaters from a top Polish skating club, i.e. junior figure skating soloists attending a 10-day training camp at the Central Sport Centre. Participants were $14-15$ years old (mean $14.4 \mathrm{y} \pm 0.3 \mathrm{SD}$ ) with an average body weight of $51 \pm 5 \mathrm{~kg}$ and height of $159 \mathrm{~cm} \pm 4 \mathrm{SD}$. Their length of time in professional training was 8 years (mean $8.5 \pm 0.5 \mathrm{SD}$ ). Figure skating in Poland is experiencing a crisis; in the 14-15 year old age group there are only 20 female trainees in this discipline. Most of them are in one club, Unia Oświęcim, which has a history of achieving high athletic performance in Poland and in the international arena, and continues to do so.

Investigating skaters at a training camp ensured a similar diet, circadian rhythm (similar bed times and wake up times), and training intensity. Based on their responses to our questionnaire, the respondents' diets before the camp was poor in vitamins, including A, C and $\mathrm{E}$. The athletes were sexually mature as noted in the interviews. In addition to the interview, the coach kept detailed records of the menstrual cycles of the skaters to take this into account during training. Our athletes menstruated regularly. Twelve of them were in the estrogenic phase and only two were in the progesterone phase (18th and 20th days of the cycle). Based on the date of their first menarche, we did not note any acceleration or deceleration in development.

The skaters were divided into two groups: one group received dietary supplementation with vitamins (A, C and $E$ ) and the other group received a placebo. The group assignments were based on individual competition rankings. The supplemented group included the athletes ranked 1, 3, 5, 7 etc. on the list, while the unsupplemented group included the athletes ranked 2, 4, 6, 8, etc. According to the guidelines of the Helsinki Declaration, participants in the experiment and their parents were informed in detail about the test procedure and provided their written consent for participation in the project. The study protocols received ethical approval from the Ethical Committee of the Regional Medical Chamber (KB-27/14).

\section{Training}

The camp took place in the Olympic Training Center in June 2013. During the camp, the skaters were subjected to 1395 minutes of training, which was prepared and approved by their coach and involved different training zones determined on the basis of heart rate measured and recorded by a Sport Tester (Table 1). A total time of 10 minutes was designated for the phosphocreatine, 850 minutes for the lactate, and 535 minutes for the oxygen training zone. The average daily training lasted 125 minutes. A typical daily schedule and training load are presented in Figure 1 and in Table 1.

\section{Supplementation}

None of the participating athletes was taking vitamin supplements at the start of the experiment. Exceptionally small doses of vitamins were taken for a short time in cases of sickness. Considering the age of athletes and the potential negative impacts of hypervitaminosis on health, vitamins were supplemented at the doses recommended for young people as follows: $16 \mu \mathrm{g} / \mathrm{kg} /$ day vitamin A, $8 \mathrm{mg} / \mathrm{kg} /$ day vitamin $C$, and $1 \mathrm{mg} / \mathrm{kg} /$ day vitamin $\mathrm{E}$. These doses are in accordance with the Polish standards for this age group. Vitamins given to the skaters in the supplemented group were dissolved in orange juice and served once daily during the morning meal. The unsupplemented group received orange juice without added vitamins. The vitamin supplement was produced by 
Table 1 Ten days training load and specific type of physical exercises during the camp

\begin{tabular}{|c|c|c|c|c|c|c|c|c|c|c|c|}
\hline \multicolumn{7}{|c|}{ Training loads performed by the subjects } & \multicolumn{5}{|c|}{ Specific type of physical exercises } \\
\hline Day of week & AP [min] & Mean HR & $\begin{array}{l}\text { MAAP } \\
\text { [min] }\end{array}$ & Mean HR & $\begin{array}{l}\text { ANLP } \\
\text { [min] }\end{array}$ & Mean HR & Day period & $\begin{array}{l}\text { Specific } \\
\text { training* } \\
\text { [min] }\end{array}$ & $\begin{array}{l}\text { Strength } \\
\text { [min] }\end{array}$ & $\begin{array}{l}\text { Running } \\
\text { [min] }\end{array}$ & $\begin{array}{l}\text { Swimming** } \\
\text { [min] }\end{array}$ \\
\hline \multirow[t]{2}{*}{ Tuesday } & 90 & $162( \pm 5)$ & 60 & $185( \pm 10)$ & - & - & Morning & 45 & 60 & & \\
\hline & & & & & & & Evening & & & 35 & 45 \\
\hline \multirow[t]{2}{*}{ Wednesday } & 45 & $164( \pm 10)$ & 110 & $182( \pm 8)$ & - & - & Morning & 45 & 50 & & \\
\hline & & & & & & & Evening & & & 40 & 45 \\
\hline \multirow[t]{2}{*}{ Thursday } & 45 & $160( \pm 5)$ & 90 & $179( \pm 8)$ & 5 & $190( \pm 10)$ & Morning & 45 & 60 & & \\
\hline & & & & & & & Evening & & & 35 & 45 \\
\hline \multirow[t]{2}{*}{ Friday } & 40 & $167( \pm 5)$ & 110 & $180( \pm 10)$ & - & - & Morning & 45 & 50 & & \\
\hline & & & & & & & Evening & & & 40 & 45 \\
\hline \multirow[t]{2}{*}{ Saturday } & 90 & $165( \pm 7)$ & 60 & $185( \pm 7)$ & - & - & Morning & 45 & 60 & & \\
\hline & & & & & & & Evening & & & 40 & 45 \\
\hline Sunday & Free day & & & & & & & & & & \\
\hline \multirow[t]{2}{*}{ Monday } & 45 & $159( \pm 5)$ & 100 & $180( \pm 6)$ & - & - & Morning & 45 & 60 & & \\
\hline & & & & & & & Evening & & & 40 & 45 \\
\hline \multirow[t]{2}{*}{ Tuesday } & 90 & $158( \pm 5)$ & 60 & $181( \pm 5)$ & - & - & Morning & 45 & 50 & & \\
\hline & & & & & & & Evening & & & 40 & 45 \\
\hline \multirow[t]{2}{*}{ Wednesday } & 45 & $158( \pm 10)$ & 60 & $180( \pm 5)$ & - & - & Morning & 45 & 60 & & \\
\hline & & & & & & & Evening & & & 40 & 45 \\
\hline \multirow[t]{2}{*}{ Thursday } & 45 & $158( \pm 10)$ & 95 & $186( \pm 5)$ & 5 & $192( \pm 12)$ & Morning & 45 & 50 & & \\
\hline & & & & & & & Evening & & & 35 & 45 \\
\hline \multirow[t]{2}{*}{ Friday } & - & - & 105 & $182( \pm 4)$ & - & - & Morning & 45 & 60 & & \\
\hline & & & & & & & Evening & & & 40 & 45 \\
\hline Total Load [min] & 535 & & 850 & & 10 & & $\begin{array}{l}\text { Total Load } \\
\text { [min] }\end{array}$ & 450 & 560 & 385 & 450 \\
\hline Total & 1395 & & & & & & Total & 1395 & & & \\
\hline
\end{tabular}

AP - Anaerobic Performance; MAAP - Mixed Aerobic-Anaerobic Performance; ANLP - Anaerobic Non Lactate Performance.

*Specific training - jumps on dry, lift and technical elements of figure skating.

**Exercises at the pool were treated as health wellness.

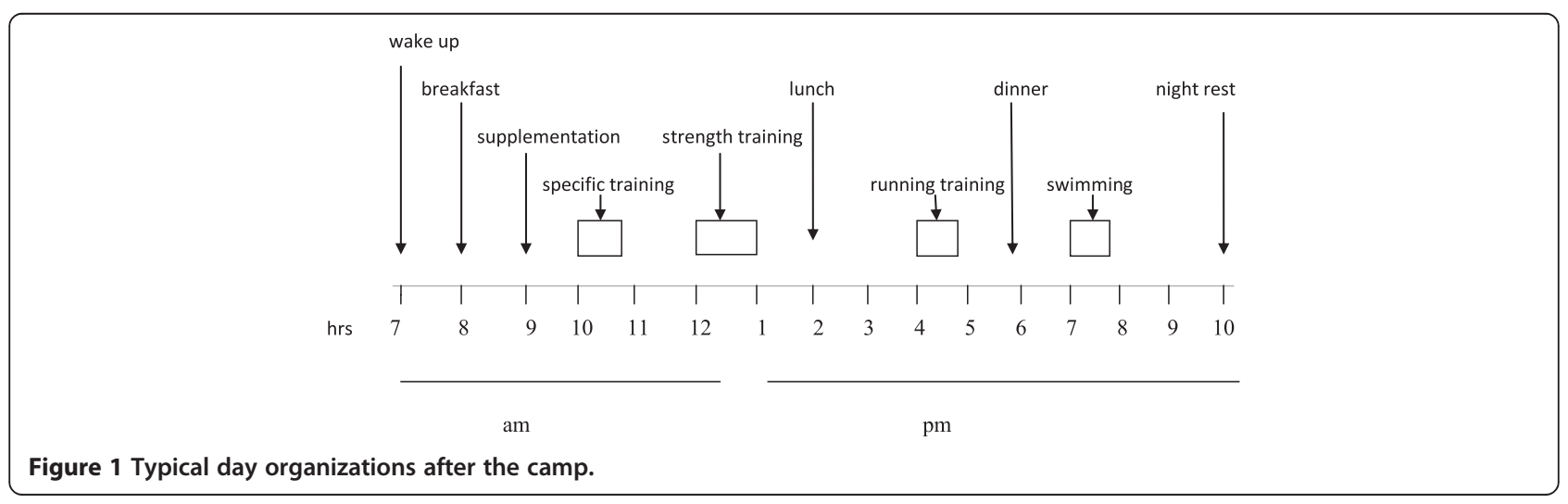


TRIPOL pharmacy and was available in solution. The athletes received vitamin supplementation only during the camp.

\section{RNA extraction and quantitative real-time polymerase chain reaction (qRT-PCR)}

Two $\mathrm{ml}$ of peripheral blood were collected from the ulnar vein of each participant at the beginning and end of the training camp. Prior to RNA extraction, erythrocytes were lysed and discarded using RBCL buffer (A\&A Biotechnology, Poland). The leukocytes were lysed using Fenozol (A\&A Biotechnology, Poland) and the RNA was subsequently precipitated by the method described by Chomczynski and Sacchi [21]. The extracted RNA was treated with DNaseI (Invitrogen) to digest any remaining DNA. cDNA was synthesized using the Transcript Me system (Blirt, Gdańsk, Poland) as per the manufacturer's instructions. A mix of $10 \mu \mathrm{L}$ master mix, $2 \mu \mathrm{L}$ enzyme mix with M-MuLV reverse transcriptase and $2 \mu \mathrm{g}$ RNA, and water, up to a final volume of $20 \mu \mathrm{L}$ was added to each tube. Samples were incubated at $25^{\circ} \mathrm{C}$ for $10 \mathrm{~min}$, $55^{\circ} \mathrm{C}$ for $30 \mathrm{~min}$ and $85^{\circ} \mathrm{C}$ for $5 \mathrm{~min}$. qRT-PCR analyses for HSPA1A and HSPB1 were performed using the Step One real-time PCR system (Applied Biosystems). Each qRT-PCR reaction mix consisted of $10 \mu \mathrm{l}$ Semi Fast Sybr Green qPCR master mix (Biolone, UK), $2 \mu \mathrm{l}$ of cDNA, $0.8 \mu \mathrm{L}$ of each primer in $10 \mathrm{pM}$ concentrate, in a final volume of $20 \mu \mathrm{L}$. Thermal cycling conditions included an initial hold at $95^{\circ} \mathrm{C}$ for 2 minutes, and than 40 cycles of $95 \mathrm{oC}$ for 15 seconds, $60^{\circ} \mathrm{C}$ for 10 seconds and $72^{\circ} \mathrm{C}$ for 20 seconds. All samples were assayed in triplicate. Primer sequences are listed in Table 2. Target gene expression was normalized to the expression of the reference gene Tata Box Protein (TBP).

\section{Statistical analysis}

Relative gene expression levels were calculated using the standard curve method. The normality of the distribution was checked with the Shapiro-Wilk test. For parametric analysis, the $t$-test for dependent samples (comparison of HSPB1 expression before and after the camp) and the $t$-test for independent samples (comparisons between the supplemented and unsupplemented groups) were utilized. For non-parametric analyses, the

Table 2 Sequence of primer used to PCR

\begin{tabular}{ll}
\hline Genes & Primer sequence: \\
\hline HSPATA & Forward primer: ACTCCCGTTGTCCCAAGGCTTC \\
& Reverse primer: TCTGTCGGCTCCGCTCTGAGAT \\
HSPB1 & Forward primer: AAGGATGGCGTGGTGGAGATCA \\
& Reverse primer: GAGGAAACTTGGTGGGGTCCA \\
TBP & Forward primer: TGGACTGTTCTCACTCTTGGC \\
& Revere primer: TTCGGAGAGTTCTGGGATTGTA \\
\hline
\end{tabular}

Wilcoxon test (comparison of HSPA1A expression before and after the camp) and two-way ANOVA (comparison between groups for the two target genes) were used. Analysis of covariance (ANCOVA) was used to adjust for baseline values and to provide an unbiased estimate of the mean between-group differences (supplemented vs unsupplemented) in the expression of HSPA1A and HSPB1. All analyses were performed in Graph Pad Prism 6.0 (www.graphpad.com), except for the two-way ANOVA way and ANCOVA, which were done using STATISTICA version 10 (www.statsoft.com) Differences were considered statistically significant if $\mathrm{p} \leq 0.05$.

\section{Results}

Relative HSPA1A and HSPB1 mRNA expression in the supplemented and unsupplemented groups are presented in Figures 2 and 3. In the unsupplemented group, there was a non-significant, $100 \%$ change in the expression of HSPA1A mRNA from before the camp to after the camp. Conversely, there was an approximately $38 \%$ statistically significant $(\mathrm{p}<0.02)$ reduction in the relative expression of HSPA1A mRNA in the supplemented group over the study period (Figure 2). There were no significant between-group differences in the basal expression of the target genes before the camp.

Figure 2 shows the data of expression HSPA1A m-RNA involving the unsupplemented and supplemented groups, measured before and after the camp. To allow better visualization of the changes in relative expression, the precamp expression levels of both groups were set to 1 .

The mean data of HSPB1 m-RNA involving the unsupplemented group and the supplemented group are presented in Figure 3. To allow better visualization of changes in relative expression, the pre-camp expression levels of both groups were set to 1 . There was a 0.38 -

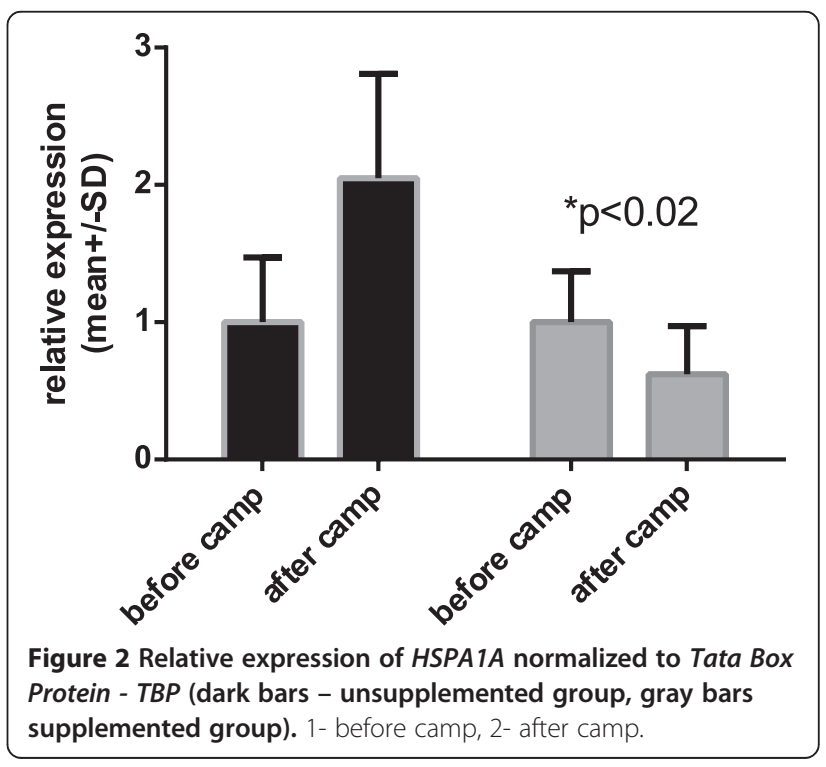




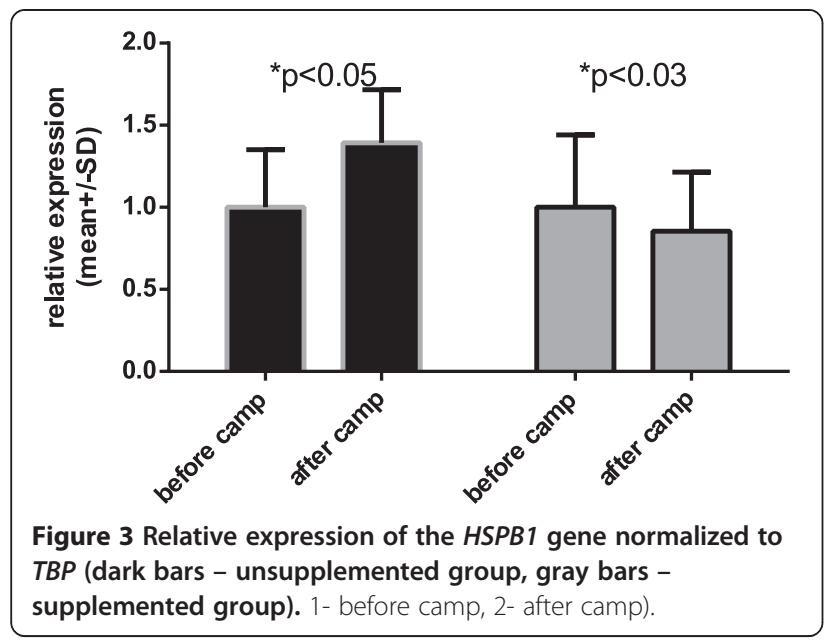

fold increase in $H S P B 1$ in the unsupplemented group $(\mathrm{p}=0.043)$ and a 0.16 -fold decrease in the supplemented group ( $p=0.023)$. However, there were no significant between-group differences in the basal expression of the target genes before the camp. There were betweengroup differences in the relative expression levels of both HSPA1A and HSPB1 mRNA after the camp; however, the differences in HSPA1A mRNA expression were more prominent. Supplementation also changed the expression of the HSPA1A chaperone, HSPB1, relative to basal levels. We assume that the training camp eliminates the potential confounding influences of factors such as dietary differences, additional personal activities besides training, and other environmental conditions on the gene expression. Of course, personal sensitivity to exercise and supplementation can vary and equivalent environmental conditions cannot control for intrinsic differences in the expression of the target genes between individuals. For this reason, we investigated the relative changes in gene expression levels. The expression levels of HSPA1A were more variable among individuals than were the expression levels of HSPB1 (Figures 4, 5, 6 and 7).
When the individual data for HSPA1A mRNA expression are considered, four athletes in the unsupplemented group had a two-fold increase in expression over the study period. Two other skaters showed less prominent changes, but their expression levels were also elevated. Only one of the skaters in the unsupplemented group had a decrease in the relative expression of HSPA1A mRNA (by approximately $50 \%$ ).

Among the skaters receiving supplementation, the relative expression of the HSPA1A transcript decreased in all seven athletes. However, the magnitude of the change varied between individuals.

In general, the direction of the changes in relative gene expression were in line with the average results for the whole group. The unsupplemented athletes, with the exception of one female athlete, showed increased HSPB1 expression to pre-camp levels (Figure 6). This increase was not dependent on the initial level of expression, and showed inter-individual differences. Relative expression of $H S P B 1$ decreased in all of the supplemented athletes; however, this change was less prominent than the change in HSPA1A expression (Figure 7).

Two-way ANOVA revealed a statistically significant group $\mathrm{x}$ time interaction for both target genes (Table 3). Analysis of covariance (ANCOVA), after considering the basal (pre-camp) value showed a significant difference between the groups in HSPA1A expression $(\mathrm{p}<0.01)$ and no significant between-group difference in $H S P B 1$ expression $(\mathrm{p}=0.17)$.

\section{Discussion}

There are many reports in the literature on the influence of oxidative stress during physical activity on the development of the inflammatory response and the resulting induction of HSP synthesis $[5,18,19]$. Under conditions of physical effort, the overexpression of genes encoding for HSP helps cells survive by protecting them from apoptosis. Morton et al. [22] claimed that the overexpression of HSP genes occurs after crossing a critical

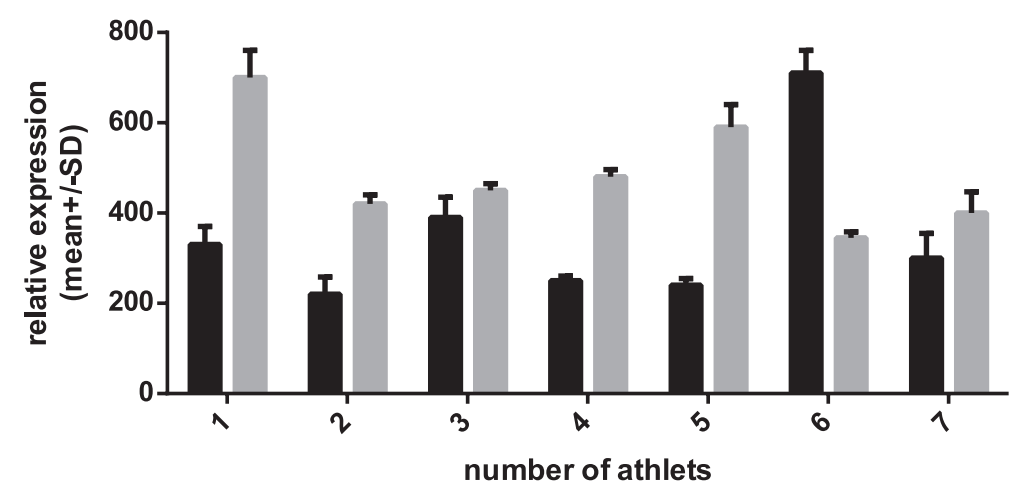

Figure 4 Individual changes in HSPA1A/TBP expression in not supplemented group measured before (dark bars) and after (gray bars) the camp. 


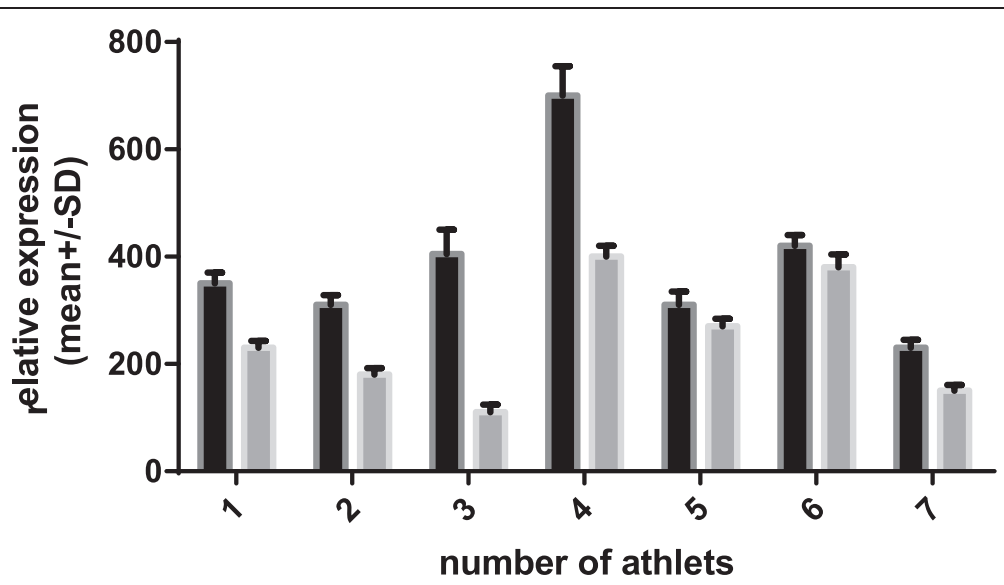

Figure 5 Individual changes in HSPA1A/TBP expression in supplemented group measured before (dark bars) and after (gray bars) the camp.

threshold, which is determined by individual difference in HSP expression propensity, training level, and also ROS levels. Evidence suggests that the level of HSP gene expression may indicate stress on the organism $[5,18,19]$; however, it is difficult to interpret changes in HSP gene expression. An increase in expression may indicate a high level of exposure to a stressor and that the critical threshold has been crossed. However, a decrease in the expression of these genes may reduce the organism's ability to tolerate stress [22].

Lui et al. [5], Tauler et al. [18] and Aguilo et al. [19] have all reported that an increase in antioxidant status will result in a decrease in oxidative stress and, consequently, the applied physical effort will result in lower stress. In this study, we used the group setting of an intense skating training camp to eliminate variations in diet, circadian rhythm, and additional, uncontrolled physical activity.
It is difficult to compare our results to previously published data since there have been few reports on this topic. The studies that have been performed used different experimental conditions, such as the nature of the physical exercise [23-26], the gender of the participants $[4,27]$, the level of commitment to the sport (recreational or professional), various supplementations [18], and diverse tissues as the source of RNA. In this study, we examined the expression of HSPA1A and HSPB1 in the leukocytes of junior female figure skaters. To our knowledge, there are no similar data available in the literature. The response to physical exercise is not only local but systemic, making analysis of relative gene expression in peripheral blood leukocytes a reasonable indicator of the whole body response to our experimental intervention [28]. Therefore, we hypothesized that antioxidant vitamins would influence the expression in leukocytes of genes which are known to be induced by oxidative stress

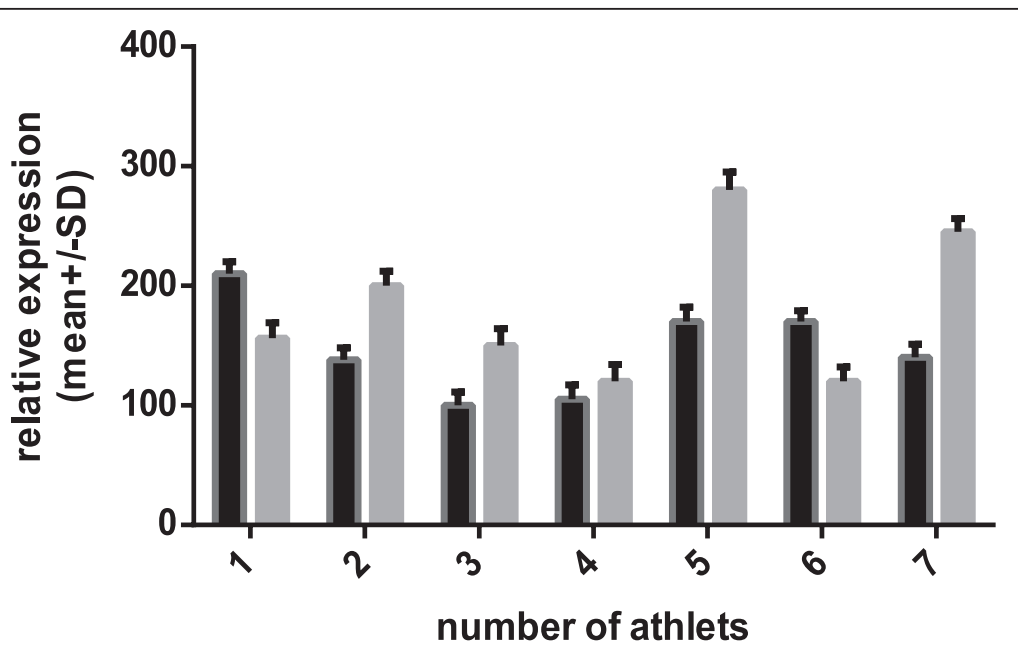

Figure 6 Individual changes in HSPB1/TBP expression in not supplemented group measured before (dark bars) and after (gray bars) the camp. 


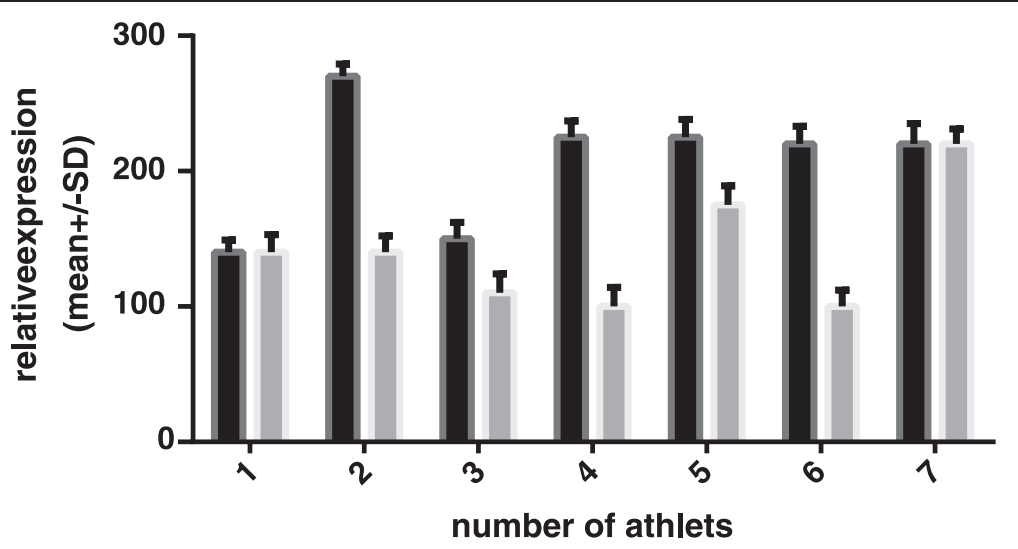

Figure 7 Individual changes in HSPB1/TBP expression in supplemented group measured before (dark bars) and after (gray bars) the camp.

[2,3]. Aguilo et al. [19] showed the influence of vitamin A, E, and beta carotene supplementation in a group of 18 male amateur athletes who were randomly assigned to groups. They found that physical exercise decreased the antioxidative status of the unsupplemented group only. In another study involving a group of amateur athletes, antioxidant supplementation for three months prior to high intensity training was shown to increase the antioxidative status of their leukocytes [18].

In contrast, Taghiyar et al. [29] examined vitamin C and $E$ supplementation in a group of women practicing aerobics and found a correlation between supplementation and decreased levels of markers of muscle damage. Interestingly, decreases in the baseline expression levels of HSPA1A have been seen as a training adaptation in highly qualified athletes in comparison to a control group (data not published). Due to the small amount of genetic research done on professional athletes, it is difficult to choose a suitable methodology for studies such as this one.

More data exist regarding changes in HSPA1A expression after physical exercise than exist for HSPB1, but they remain ambiguous. The results vary between studies since changes in HSPA1A expression are dependent on the type of effort and the type of muscle fiber involved in the particular exercise [25,26]. Thus, Ryan et al. [30], in a study involving young men subjected to two hours of effort on a treadmill under heat stress conditions, noted only minor changes in HSPA1A expression in peripheral blood leukocytes. On the other hand, Lui et al. [5] examined a group of rowers and observed elevated expression of HSPA1A even four weeks after the training period. Therefore, it seems reasonable to examine athletes during their rest phase, as well as during physical training. Despite great interest in heat shock proteins, it seems that only some of the stress factors that can induce expression of HSP encoding genes (such as physical effort) are currently known [31].

Our research involved a group of young junior figure skaters and there are no published, comparable data from this particular discipline. Additionally, the tested group had never undergone supplementation. Besides the type of sport, the gender of the participants may also influence the results. Since hormones can have a huge impact on gene expression, comparing females and males is a difficult task. Chang et al. [27] supplemented women with estrogen for three days and did not observe any changes in the level of HSP70 protein in leukocytes; however, this does not exclude between-gender differences. We expect that the response to supplementation of athletes who are in the same estrogenic phase should be similar. However, it is difficult to discuss our results in this regard due to the lack of comparable studies in the literature. We recognize that the potential for

Table 3 Results ANOVA two - way and power of analysis

\begin{tabular}{|c|c|c|c|c|c|c|c|c|}
\hline \multirow[b]{2}{*}{ gene } & \multirow{2}{*}{$\begin{array}{l}\text { Supplemented group } \\
\text { PRE }\end{array}$} & \multicolumn{2}{|c|}{ Un-supplemented group } & \multicolumn{4}{|l|}{ ANOVA 2-way } & \multirow{2}{*}{$\begin{array}{l}\text { ANCOVA } \\
\text { covariance }\end{array}$} \\
\hline & & POST & PRE & POST & Differences group $\mathrm{x}$ time & Effect size(ES) & Power & \\
\hline & \multicolumn{7}{|c|}{ Normalized expression (Mean \pm SD) } & \\
\hline HSPA1A & $389.3 \pm 151.2$ & $245.7 \pm 111.5$ & $348.6 \pm 169.8$ & $483.6 \pm 122.2$ & $\leq 0.03$ & 0.37 & 0.68 & $p \leq 0.04$ \\
\hline HSPB1 & $207.1 \pm 45.99$ & $140.7 \pm 44.20$ & $147.6 \pm 39.00$ & $181.6 \pm 62.30$ & $\leq 0.05$ & 0.52 & 0.91 & $p \leq 0.03$ \\
\hline
\end{tabular}


extrapolation of our results, which are based on the responses of a specific group of 14 people, to the general population is limited. However, supplementation with antioxidant vitamins significantly reduced the expression of HSPA1A and HSPB1 genes in our study participants, which might indirectly indicate an increased antioxidant capacity of their leukocytes and, therefore, a lower need for the expression of genes involved in the apoptotic pathway and the degradation of damaged proteins.

\section{Conclusion}

Our results indicate that supplementation with antioxidant vitamins such $\mathrm{A}, \mathrm{C}$ and $\mathrm{E}$ significantly decreases the expression of HSPA1A and HSPB1 in the leukocytes of young soloist figure skaters subjected to heavy training load. It is likely that our results were affected by the vitamin-deficient status of the athletes at the start of the study; growing young women involved in high intensity training should be consuming much higher levels of vitamins than these women were.

\section{Abbreviations \\ ROS: Reactive oxygen species; TAS: Total antioxidant status; TBP: Tata box protein gene; HSPA1A: Gene coding HSP70 kDa protein; HSPB1: Gene coding HSP27 kDa protein.}

\section{Competing interests}

The authors declared that they have no competing interests.

\section{Authors' contributions}

MŻ, ZJ, GC, MM-S, AN-Z. All authors read and approved the final manuscript.

\section{Authors' information}

Małgorzata Żychowska, Graduate of Jagiellonian University Cracow, Poland. Associated with Physiology, Biochemistry and Genetic in Sport.

Zbigniew Jastrzębki, Scientist in Sport Physiology, main physiologist of top Polish football and handball teams.

Alicja Nowak-Zaleska, Graduate of University in Gdańsk, Diagnostician in Microbiology, Associated with Physical Education.

Grzegorz Chrusciński, Graduate Karol University Prague, coach in the discipline of ice-hockey, associated also with figure skaters.

\section{Acknowledgments}

Authors wish to thank the leading Polish figure skating coach in Unia Oswięcim, Iwona Mydlarz Chruściński, for her conduct and control of the training process.

We also extend our thanks to Joanna Pyczek, from the Institute of Human Genetics, Georg-August University in Göttingen, for her help in the selection of methods to test gene expression and assistance in the interpretation of our results.

\section{Author details}

${ }^{1}$ Department of Health Promotion, Gdańsk University of Physical Education and Sport, UI. Górskiego 1, 80-360 Gdańsk, Poland. '2Department of Physical Education, Gdańsk University of Physical Education and Sport, Ul. Górskiego 1, 80-336 Gdańsk, Poland.

Received: 31 March 2014 Accepted: 16 January 2015

Published online: 11 February 2015

\section{References}

1. Morimoto RI. Regulation of the heat shock transcriptional response; cross talk between a family of heat shock factors, molecular chaperones, and negative regulators. Genes Dev. 1998;12:3788-96.
2. Arya R, Mallik M, Lakhotia SC. Heat shock genes-integrating cell survival and death. J Biosci. 2007;32(3):595-6. 601-602.

3. Kaźmierczuk A, Kiliańska Z. The pleiotropic activity of heat-shock proteins. Post Hig Med Dosw. 2009:63:503-21.

4. Kregel KC. Heat shock proteins: modifying factors in physiological stress responses and acquired thermotolerance. Appl Physiol. 2002;92(5):2177-86.

5. Liu Y, Lormes W, Baur C, Opitz-Gress A, Altenburg D, Lehmann M, et al. Human skeletal muscle Hsp70 response to physical training depends on exercise intensity. Int J Sports Med. 2000;21:351-5.

6. Zeibig J, Karlic H, Lohninger A, Damsgaard R, Smekal G. Do blood cells mimic gene expression profile alterations known to occur in muscular adaptation to endurance training? Eur J Appl Physiol. 2005;95(1):96-104.

7. Fehrenbach EJ. Multifarious microarray-based gene expression patterns in response to exercise. Appl Physiol. 1985;102(1):7-8.

8. Acunzo J, Katsogiannou M, Rocchi P. Small heat shockproteinsHSP27 (HspB1), aB-crystallin (HspB5) and HSP22 (HspB8) as regulators of cell death. Int J Biochem Cell Biol. 2012;44(10):1622. -31, 2012.

9. Nagaraja GM, Kaur P, Asea A. Role of human and mouse HSPB1 in metastasis. Curr Mol Med. 2012;12(9):1142-50.

10. Fehrebach E, Passek F, Niess AM, Pohla H, Weinstock C, Dickhuth $H$, et al. HSP expression in human leukocytes is modulated by endurance exercise. Med Sci Sports Exerc. 2000;32:592-600.

11. Pyne DB. Exercise-induced muscle damage and inflammation: a review. Aust J Sci Med Sport. 1994;26:49-58.

12. Gutteridge JM, Halliwell B. Antioxidants: molecules, medicines, and myths. Biochem Biophys Res Commun. 2010;393(4):561-4.

13. Mastaloudis A, Leonard S, Traber M. Oxidative stress in athletes during extreme endurance exercise. Free Radic Biol. 2001;31:911-22.

14. Cannon J, Blumberg J. Acute phase immune responses in exercise. In: Sen C, Packer L, Hanninen O, editors. Handbook of oxidants and antioxidants in exercise. New York: Elsevier; 2000. p. 177-94.

15. Sjodin B, Hellsten Westing Y, Apple F. Biochemical mechanisms for oxygen free radical formation during exercise. Sports Med. 1990;10:236-54.

16. McGinley C, Shafat A, Donnelly AE. Does antioxidant vitamin supplementation protect against muscle damage? Sports Med. 2009;39:1011-32.

17. Skjønsberg $\mathrm{OH}$, Nielsen $\mathrm{HG}$, Lybe T. Effect of antioxidant supplementation on leucocyte expression of reactive oxygen species in athletes. Scand J Clin Lab Invest. 2008;68(7):526-33.

18. Tauler P, Aguiló A, Gimeno I, Fuentespina E, Tur JA, Pons A. Response of blood cell antioxidant enzyme defences to antioxidant diet supplementation and to intense exercise. Eur J Nutr. 2005;45(4):187-95.

19. Aguilo A, Tauler P, Fuentespina E, Villa G, Cordova A, Tur JA, et al. Antioxidant diet supplementation influences blood iron status in endurance athletes. Int J Sport Nutr Exerc Metab. 2004;14(2):147-60.

20. Büttner $P$, Mosig S, Lechtermann A, Funke H, Mooren FC. Exercise affects the gene expression profiles of human white blood cells. J Appl Physiol. 2007;102(1):26-36

21. Chomczynski P, Sacchi N. Single-step method of RNA isolation by acid guanidinium thiocyanate-phenol-chloroform extraction. Anal Biochem. 1987;162(1):156-9.

22. Morton JP, Kayani AC, McArdle A, Drust B. The exercises-induced stress response of skeletal muscle, with specific emphasis on humans. Sports Med. 2009;39:643-62.

23. Donnikov AE, Shkurnikov MU, Akimov EB, Tonevitsky AG. Relationship between the degree of cardiovascular adaptation and Th1/Th2 polarization of immune response. Bull Exp Biol Med. 2008;146(4):462-5.

24. Sakharov DA, Maltseva DV, Riabenko EA, Shkurnikov MU, Northoff $\mathrm{H}_{\text {, }}$ Tonevitsky AG, et al. Passing the anaerobic threshold is associated with substantial changes in the gene expression profile in white blood cells. Eur J Appl Physiol. 2012;112(3):963-72.

25. Ecochard L, Lhenry F, Sempore B, Favier R. Skeletal muscle HSP72 level during endurance training: influence of peripheral arterial insufficiency. Pflugers Arch. 2000;440(6):918-24.

26. Radák Z, Naito H, Kaneko T, Tahara S, Nakamoto H, Takahashi R, et al. Exercise training decreases DNA damage and increases DNA repair and resistance against oxidative stress of proteins in aged rat skeletal muscle. Pflugers Arch. 2002;445(2):273-8.

27. Chang RT, Lambert GP, Moseley PL, Chapler FK, Gisolfi CVJ. Effect of estrogen supplementation on exercise thermoregulation in premenopausal women. J Appl Physiol. 1998;85(6):2082-8. 
28. Maltseva DV, Ryabenko EA, Sizova SV, Yashin DV. Effect of exercise on the expression of HSPBP1, PGLYRP1, and HSPATA genes in human leukocytes. Bull Exp Biol Med. 2012;153:6867-9.

29. Taghiyar M, Darvishi L, Askari G, Feizi A, Hariri M, Shokri N, et al. The effect of vitamin $C$ and $E$ supplementation on muscle damage and oxidative stress in female athletes. A clinical trial. Int J Prev Med. 2013:4(1):16-23.

30. Ryan AJ, Gisolfi CV, Moseley PL. Synthesis of 70K stress protein by human leukocytes: effect of exercise in the heat. J Appl Physiol. 1991;70:466-71.

31. Njemini R, Vanden Abeele M, Demanet C, Lambert M, Vandebosch S, Mets T. Age-related decrease in the inducibility of heat-shock protein 70 in human peripheral blood mononuclear cells. J Clin Immunol. 2002;22:195-205.

\section{Submit your next manuscript to BioMed Central} and take full advantage of:

- Convenient online submission

- Thorough peer review

- No space constraints or color figure charges

- Immediate publication on acceptance

- Inclusion in PubMed, CAS, Scopus and Google Scholar

- Research which is freely available for redistribution 